\section{Sense Coverage}

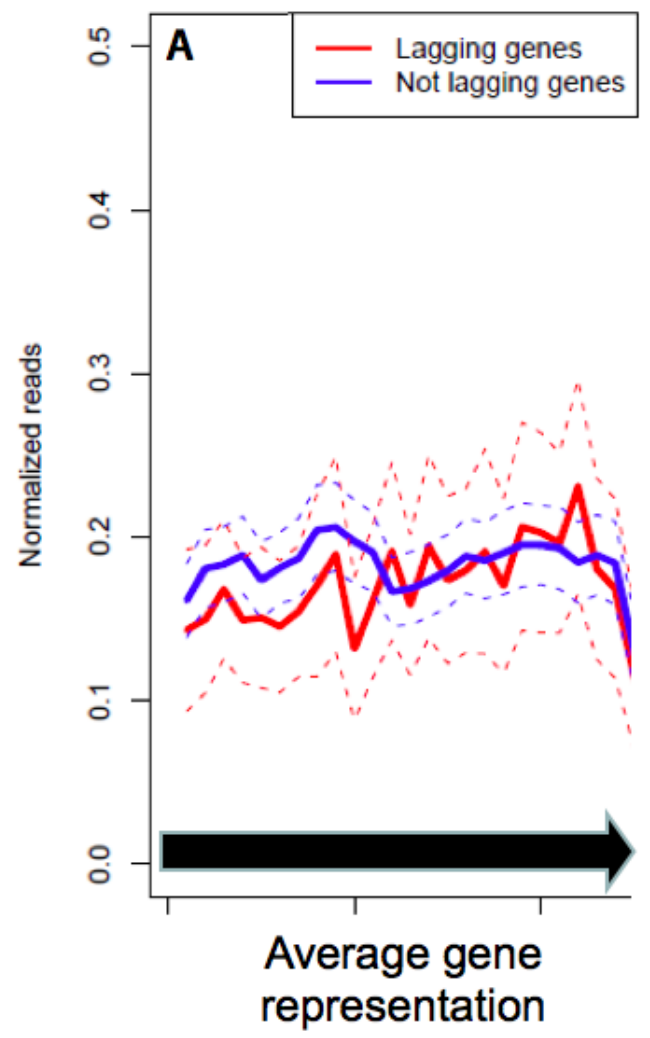

Anti-Sense Coverage

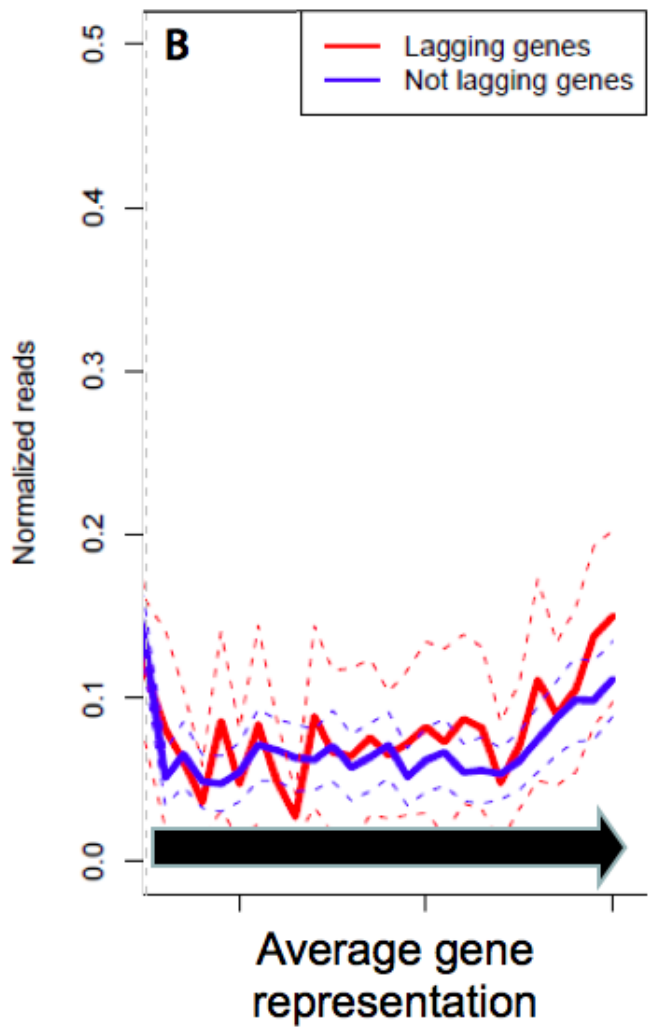

